\title{
Appreciation of Architecture by Common Man: Writing Architecture
}

\author{
Amarendra Kumar Das ${ }^{1 *}$ and BarshaAmarendra ${ }^{2}$ \\ ${ }^{1}$ Department of Design, IIT Guwahati, India \\ ${ }^{2}$ Department of Architecture, VNIT, India
}

Submission: March 14, 2017; Published: September 22, 2017

*Corresponding author: Amarendra Kumar Das, Department of Design, IIT Guwahati, India, Email: dasak@iitg.ernet.in

\section{Opinion}

Some people thrive on change at the very same time others will do all they can to resist it. Is advocating these changes as a good thing, always right? It is not just the change that is beneficial for us; it is our capability to convert this change into an opportunity that makes us understand things in a better way. Change is the backbone of progression, evolution but at times some loopholes find their way which must be properly addressed or could turn into a perilous scenario. In a nutshell same is the case of evolution in field of architecture in past few decades.

Architecture and its understanding by the society must go hand in hand. Dating back to any age till renaissance the difference was not as vast as it is in the contemporary times. And this difference started to set its root in industrial age. Sensitivity of architects towards architecture was always the same but thoughts of other parts of society by dint seemed to have same sensitivity towards the edifices. 'Less is more'-by Mies was reframed as 'less is bore' by Robert Venturi. The ornamentation which was vocabulary of architecture at time was rather deputed as crime by Adolf Loos. But no such views that would show their sensitivity towards the change and pace in build form, from other field seem to find the light. 'Architecture is a visual art, and the buildings speak for themselves', a famous quote by Julia Morgan aptly expresses the beauty of built form and the adroitness of architecture.

Art tends to construe with architecture and common man has always been fascinated by this bond. Since the beginning of civilizations, architecture has played an important role in communicating the culture and lifestyle of people. Basically, art, architecture and culture have always been in concordance and their existence stands as an evidence in anthropological study. The evolution of architecture occurred based on its interpretation by common man. Any work of art or architecture is appreciated on its capability of rendition; and according to psychology, common man cognizes and acknowledges the beauty of art when it is easy to decipher. Hence, the architecture of an ad hoc time period gives meticulous details about its lifestyle and culture. There is a beautiful quote of Mies Van Der Rohe, Architecture is the will of an epoch translated into space' which emphasizes architecture as the time machine for culture.

However, the perspective of common man towards architecture changed with time and that change brought about some impolitic breach between them. This can be seen from the works of famous architects of any time between ancient and contemporary periods. It is also observed that this schism grows from ancient to contemporary and to obviate it, the cause of this change in vantage point must be eliminated. Some examples in the history of architecture appropriately represent the gap in actual architecture and the apprehension of common man. For instance, modern architecture comprised of two typologies viz. The rationalist architects who were too engulfed in form, function, classicism and rudimentary principles and the architects of art nouveau on the other hand who were focused on biometric and sensitive architecture. This severance was between the thoughts of architects, so the common man would already be put into perplexity.

The difference in their thoughts can be easily observed as- Adolf Loos of the rationalist school quoted, 'ornamentation is crime', and works of Guimard and Antonio Gaudi represent extreme cases of artificial beautification. If there is a gap in the thoughts of architects itself, the architecture would obviously be affected. This made the common man lose interest in architecture and aroused incredulity about it. Therefore, in the post modern period, it was realized that architecture is ultimately a social art with which a society communicates its aspirations. After this period, the need to reconnect architecture with culture, art and in turn the common man was elicited. Without art and culture as the supreme part of it, architecture can never run close to a man's heart.

Hence the contemporary architecture has to put in conscientious efforts to bridge this gap by bringing back the 
erstwhile constituents of architecture. Luis Barragan says that, 'My house is my refuge, an emotional piece of architecture, not a cold piece of convenience.' In this substantial statement he has put forth a great metaphorical link of architecture and the emotions and sentiments of man. A common man does not build house as mere shelter but as a haven which removes his emotional stresses, soothes his mind and makes him forget all his pain. He wants a home rather than a house. This can be achieved only if the common man understands architecture. The common man should be able to feel, he should be able to relate himself with the structure around him.

This can be done by making the built form easily legible to him. Minimal complexity in form, functional design and an architecture that connects to nature is something that communicates with the user of a space by itself. We need a building that is so friendly to the user that it expresses itself to every gander. The building should smile to the person looking at it and welcome him in, irrespective of the man's profession. After all, who wouldn't want to enter a building that greets you in?

Architecture symbolizes its emotions through its structure. However, the verbal expression of architecture involves a vocabulary that only architects understand. To make written architecture exoteric, it needs to be evinced prudently. The indited work should be like that of a novelist or an author, which could be interpreted by anyone. Making architecture perceptible to the common man in the simplest possible way develops a sense of oneness towards the building. Another aspect that matters while communicating architecture is the tradition of the area it is developed in. More vernacular is the architecture, better is its transmission to the common man. Every common man likes to feel involved in his surrounding environment. When the built form of an area or region is developed, it follows a certain functional pattern, as said by Louis Sullivan. So while writing architecture, due emphasis should be given on traditionalism of the architecture. This will bring the common man closer to the emotions of the building. The expression of the building evinced in written form should subtly make the reader curious about it and should arouse a feeling of familiarity and affection. Now it's high time for the architect fraternity to say no to signature architecture and question themselves that edifices must be raised for the sake of showing ones art, to let it outstand from the ground which shall keep on going alien to the allied forms.

If all buildings have their own dance then it would turn into a hideous aura and that harmony and serenity of the place would be lost which ones seemed to be united due to a rhythm in the build forms. How far is the use of architectural vocabulary justified in order to glorify the beauty of the build form? Keeping in mind that use of these articulated words is assessable by a limited part of society i.e. only the architectural fraternity, why the beauty of structures can't be glorified by using a language that even a common man can understand as well as appreciate. Is it really necessary to appreciate a structure only by emphasizing on the visual principles involved in it? My words must not be misinterpreted as that use of Architectural vocabulary should be avoided rather conscious effort by the authors must be made in order to appreciate the built form that every part of society could appreciate. "We shape our buildings and thereafter they shape us "-Winston Churchill. After all, architects are the mere developers who develop the society according to the wish and need of the society itself which in return design the society. Society is the patron for the architects.

If the architecture is not well communicated, then the ideology such as sustainability, energy efficient architecture, net zero buildings, etc. would have to fight a long battle. Communication must not be misapprehended as written communication only, rather verbal, nonverbal and visual communication also must be taken into account. In fact nonverbal communication i.e. when building communicates itself, that is the experience of the build form and environment is the best kind of communication that can happen but one cannot reach each and every place but shall need to know the design principles and the beauty of the place shall be communicated with the help of other forms of communication too.

Visual communication which comprises of graphic communication plays a great role in the same because the visuals are the best you have retaining the information in the human mind. Everyone might not be able to visualize that text but at the very same time if presented in form of $2 \mathrm{D}$ or $3 \mathrm{D}$ graphics then shall we sustain for longer period of time. For example, whenever we say Taj Mahal a two point perspective image of the Taj Mahal comes to your mind. We don't remember the text that we have read, the emails that we have seen, but the important parts of these communications can be stored in our minds. Similarly, if the written form of architecture creates an image of itself in the minds of common man, it becomes a wonderful way of communication. Communicating architecture does not only mean to glorify the work of others or to document them. Rather, when an architect gives birth to its creation, it is equally important that the idea behind the creation must be well communicated. The end product of an Architects work is not his soul work rather it is a composition of many allied fields. It is important that the client understands these aspects and the ideology behind the creation be aptly perceived. A lot of times it happens that the vision of the architect is misread by the common man and in due course the notion behind the building is lost. In cases of renovations, the true support, the backbone of the architecture is effaced. The newly evolved structure stands on the carcass of the beautiful, logical design by the previous architect whose conception was imperceptible to the common man. This is where a grave need of communicating architecture can be felt. From case studies and site visits during the sessions of academics, it has been evident that architecture needs to be transferred from generations to generations in order to maintain its integrity and defy its demise. 
And to pass it on and keep it in the run, communication medium for architecture should be potent, efficacious and trenchant. The necessity for doing this has been more and more felt in developing economies of the world, where new alien forms are intruding the skylines of various towns and cities to which local residents cannot relate to. This is creating towns and cities that are getting isolated and social fabric is getting worn out. Therefor need to communicate with people for this new architecture trend is becoming a priority. Communication plays a significant role in shaping the art, history and culture of an era. And as stated initially, they are all depicted through architecture.
Hence efficient and pertinent communication through all types of media is the apt resource of retaining the illustriousness and dignifying the beauty of architecture. In all this, proficient written communication helps in conveying the articulate nature of architecture to the layman and developing in him the sense of curiosity to apprehend and explore the magic and beauty of the same. Albeit there elicits a question, would improper communication affect the dandyism of architecture, decorous perception and observance will never fail to appreciate its beauty and shall always value its position in framing the culture and tradition of any realm.

\section{Your next submission with Juniper Publishers will reach you the below assets}

- Quality Editorial service

- Swift Peer Review

- Reprints availability

- E-prints Service

- Manuscript Podcast for convenient understanding

- Global attainment for your research

- Manuscript accessibility in different formats

( Pdf, E-pub, Full Text, Audio)

- Unceasing customer service

Track the below URL for one-step submission https://juniperpublishers.com/online-submission.php 